\title{
THE CHRONIC GASTROINTESTINAL MANIFESTATIONS OF CHAGAS DISEASE
}

\author{
Nilce Mitiko Matsuda, ${ }^{\text {IS Steven M. Miller, }}{ }^{\text {II }}$ Paulo R. Barbosa Evora \\ doi: 10.1590/S1807-59322009001200013
}

Matsuda NM, Miller SM, Évora PRB. The chronic gastrointestinal manifestations of chagas disease. Clinics. 2009;64(12):1219-24

Chagas disease is an infectious disease caused by the protozoan Trypanosoma cruzi. The disease mainly affects the nervous system, digestive system and heart. The objective of this review is to revise the literature and summarize the main chronic gastrointestinal manifestations of Chagas disease. The chronic gastrointestinal manifestations of Chagas disease are mainly a result of enteric nervous system impairment caused by $T$. cruzi infection. The anatomical locations most commonly described to be affected by Chagas disease are salivary glands, esophagus, lower esophageal sphincter, stomach, small intestine, colon, gallbladder and biliary tree. Chagas disease has also been studied in association with Helicobacter pylori infection, interstitial cells of Cajal and the incidence of gastrointestinal cancer.

KEYWORDS: Enteric nervous system; Gastrointestinal tract; Motility disorders; Chagas disease, Trypanosoma cruzi.

\section{INTRODUCTION}

Chagas disease, named after the Brazilian physician, bacteriologist and epidemiologist Carlos Chagas who first described it a hundred years ago, is a tropical parasitic disease caused by the flagellate protozoan Trypanosoma cruzi $\left(\right.$ T. cruzi). ${ }^{1-3}$

The parasite $T$. cruzi is commonly transmitted to humans and other mammals by a vector insect, the blood-sucking bugs of the subfamily Triatominae. ${ }^{1,2}$ This disease can also be transmitted by blood transfusion, organ transplantation, from a mother to her fetus and by ingestion of food contaminated with the parasites. ${ }^{4,5}$

Several years or even decades after the initial infection, approximately $30 \%$ of infected people develop medical problems from Chagas disease over the course of their lives. ${ }^{4}$ Chagas disease mainly affects the nervous system, gastrointestinal tract and heart. Most people suffer

I Departamento de Anatomia e Cirurgia, Universidade de São Paulo - Ribeirão Preto/SP, Brazil.

II Department of Physiology and Biomedical Engineering, Mayo Clinic Rochester/Minnesota, USA.

Email: nmmatsuda@uol.com.br

Tel: 55163633.0836

Received for publication on August 27, 2009

Accepted for publication on September 18, 2009 cardiac damage, including cardiomyopathy, heart rhythm abnormalities and often an apical aneurysm., 3

Approximately one third of patients can develop dilation of the gastrointestinal tract (megacolon, megaesophagus, megastomach, megaduodenum, megajejunum, megagallbladder, megacholedochus) and gastrointestinal motor disorders, such as achalasia of the cardia, disturbances of gastric emptying, altered intestinal transit and colon and gallbladder motor disorders..$^{3,4,6-18}$ Chagas disease is known to cause both central nervous system and enteric nervous system injury. ${ }^{3,4}$ The chronic gastrointestinal manifestations of Chagas disease are mainly a result of enteric nervous system injury caused by $T$. cruzi infection. ${ }^{19-25}$

The objective of this review is to revise the literature and summarize the main chronic gastrointestinal manifestations described in association with Chagas disease in the year of the hundredth anniversary of the first description of Chagas disease.

\section{DISCUSSION}

The chronic gastrointestinal manifestations of Chagas disease are described in the salivary glands, esophagus, lower esophageal sphincter, stomach, small intestine, colon, gallbladder and biliary tree.,4,6-18,26 These alterations seem to develop from both excitatory and inhibitory enteric motor 
innervation impairments. ${ }^{19-24}$ The chronic gastrointestinal manifestations of Chagas disease are described in association with Helicobacter pylori (H. pylori) infection, damage to the interstitial cells of Cajal and the incidence of gastrointestinal cancer. $^{27-34}$

From a total of 4,690 autopsies, 1,708 chagasic chronic post-mortem examinations were performed, and megacolon was the most frequent gastrointestinal manifestation, followed by megaesophagus. Megacolon associated with the megaesophagus was the third most common finding. ${ }^{35}$

\section{The salivary gland manifestations of Chagas disease}

Sialorrhea has been described in association with megaesophagus in both patients with Chagas disease and those with idiopathic megaesophagus. ${ }^{36}$ Salivary gland hypertrophy and sialorrhea have been described not only in association with chagasic megaesophagus and idiopathic achalasia, but also in association with other eating disorders, including bulimia and anorexia nervosa. ${ }^{36-38}$ Both salivary gland hypertrophy and sialorrhea seem to be related to the symptoms of vomiting and regurgitation described in these eating disorders and idiopathic and chagasic achalasia. ${ }^{36-38}$

\section{The esophagus and the lower esophageal sphincter manifestations of Chagas disease}

Chagasic achalasia and its consequence of chagasic megaesophagus are common findings in Chagas disease, and dysphagia may be the first symptom of digestive disturbances that may lead to malnutrition and severe weight loss. ${ }^{8,9,35,39,40}$

The nitric oxide (NO) donor drugs were used at the first half of the last century to increase emptying of the megaesophagus and to improve the symptoms of dysphagia in idiopathic achalasia. ${ }^{41-44}$ In chagasic achalasia, there are reports of the use of such drugs for the same purpose in the middle of the last century. However, the presentation of NO-donor drugs and their side effects has limited their use. Only later, with the presentation of such drugs in the form of tablets to be administered orally or sublingually, it was demonstrated that NO-donor drugs decrease lower esophageal sphincter pressure, improve the symptoms of dysphagia and increase megaesophagus clearance in both idiopathic achalasia and chagasic achalasia. ${ }^{45-53}$ Researchers finally demonstrated similarities between the inhibitory non-adrenergic non-cholinergic mediator and the substance released from NO-donor drugs in the late 1980s. ${ }^{54,55}$

Although chagasic achalasia presents with symptoms and radiological findings similar to those of idiopathic achalasia, some important differences are described. ${ }^{9,}{ }^{56-}$
${ }^{58}$ It has been demonstrated that, in patients with Chagas disease, pressure in the lower esophageal sphincter is lower than in normal patients, whereas the pressure is higher in patients with idiopathic achalasia. ${ }^{7,40}$ Higher pressure in the lower esophageal sphincter in idiopathic achalasia relative to that in controls has also been demonstrated by others researchers. ${ }^{59,60}$ Reduced pressure in the lower esophageal sphincter in chagasic achalasia further demonstrates that both innervations, excitatory and inhibitory, are damaged in contrast to idiopathic achalasia, where the excitatory innervation is preserved, thereby causing the pressure to be higher than in the normal subjects. ${ }^{39,40,59-61}$ Similarities are also observed in the treatments, including pharmacological, endoscopic and surgical procedures. ${ }^{62,63}$ In both cases, treatment is palliative, with an objective of decreasing lower esophageal sphincter pressure, improving esophageal emptying and relief of the symptoms of dysphagia. ${ }^{62,63}$

\section{The stomach manifestations of Chagas disease}

The megastomach is neither a common nor an important finding of gastrointestinal manifestation in Chagas disease, although alterations in both motility and secretion have been described. Delayed gastric emptying of solid meals has been demonstrated. The explanation provided for this observation is that the excitatory motor enteric neurons are damaged in Chagas disease. ${ }^{13,64}$ Fast gastric emptying of liquid meals was also demonstrated, and the explanation was related not only to impairment of the excitatory enteric neurons, but also to impairment of inhibitory enteric neurons. ${ }^{12,15}$

Given that inhibitory innervation is responsible for gastric accommodation after a meal, the stomach is not able to relax after a liquid meal once inhibitory enteric innervation is damaged, which results in rapid gastric emptying. ${ }^{12,15}$

Moreover, electrogastrography performed in patients with Chagas disease showed a higher incidence of gastric dysrhythmias in the chagasic patients than in the normal subjects. ${ }^{26}$ Another alteration demonstrated in patients with Chagas disease is that both basal and stimulated acid gastric secretion were lower than in normal subjects. ${ }^{65,66}$

\section{The small intestine manifestations of Chagas disease}

Abnormalities of interdigestive motility of the small intestine in Chagas disease have been described. ${ }^{67}$ Manometric studies of gastrointestinal motility showed abnormally slow propagation of the interdigestive migrating motor complex, which was also excessively prolonged..$^{66,67}$

Although not common, dilation of the small intestine, such as megaduodenum and megajejunum, has also been 
described..$^{14,18}$ However, fast transit in the dilated small intestine in Chagas disease has been associated with bacteria overgrowth with chronic diarrhea, malabsorption, steatorrhea and hypocalcemia that improved with oral antibiotic therapy. ${ }^{14,18}$ Patients with Chagas disease have a combination of very fast gastric emptying and abnormally delayed transit of liquids through the more distal segments of the small bowel. ${ }^{15}$ Also, disorders of absorption in the small intestine were demonstrated in Chagas disease as an abnormal increase in the absorption of carbohydrates. ${ }^{2,10}$

\section{The colonic manifestations of Chagas disease}

Another common manifestation of Chagas disease in the gastrointestinal tract is chagasic megacolon. Chronic constipation is the main symptom related to megacolon. ${ }^{4}$, 6,8,35 Although chagasic megacolon presents with symptoms and radiological findings similar to congenital megacolon, differences are also related to damage in both excitatory and inhibitory innervations. ${ }^{19,20,22,24,25}$ Manometric studies in chagasic patients have demonstrated the basal motility index and wave frequency of the sigmoid colon and rectum to be lower than in normal subjects. In addition, the studies show a lack of relaxation of the internal sphincter of the anus in the chagasic patients. ${ }^{6,11}$ Others have demonstrated an absence of the rectoanal inhibitory reflex in the chagasic megacolon, similar to that in Hirschsprung's disease. ${ }^{68,69}$ Alteration of the rectoanal inhibitory reflex in most of the chagasic patients with megacolon was demonstrated by several researchers and can be justified by the destruction of enteric motor innervations. ${ }^{6,11,19,20,22,24,25,68,70}$ The choice of surgical treatment appears to have the same indication as a solution for constipation in both chagasic and idiopathic megacolon. ${ }^{71,72}$

The incidence of diverticula in the sigmoid colon of the non-chagasic group was higher than in both the chagasic group with and without megacolon. ${ }^{73}$ Among the patients with megacolon and diverticular disease, the diverticula were always located in the non-dilated portions of the large bowel, suggesting that unfavorable conditions for the genesis or maintenance of diverticula exist in the dilated colon of the chagasic patients. ${ }^{73}$

\section{The gallbladder and the biliary tree manifestations of Chagas disease}

Gallbladder neuron counts in cholelithiasis in patients with Chagas disease have demonstrated a reduction in the number of neurons in the gallbladder wall. ${ }^{21}$ Given that the enteric excitatory motor neurons are damaged in Chagas disease, the prevalence of cholelithiasis, megagallbladder and megacholedochus is higher. ${ }^{74,75}$ Despite controversial results, a scintigraphic study of gallbladder emptying in Chagas disease showed that the gallbladder of the chagasic patients was much more sensitive to an exogenous cholecystokinetic agent and contracted in a more intense manner, with contraction starting earlier and lasting longer than among the controls, suggesting more severe impairment of the inhibitory enteric innervations. ${ }^{17}$

\section{H. pylori infection and Chagas disease}

In addition to studies in developing countries, which have a higher incidence of infection by $H$. pylori, Chagas disease has a higher incidence of peptic changes and a high frequency of peptic disease associated with $H$. pylori infection. ${ }^{29,76}$ Another study showed that the prevalence of infection by $H$. pylori was higher in the chagasic patients than in non-chagasic subjects from both urban and rural areas. ${ }^{31}$ Furthermore, H. pylori was considered a possible factor related to the etiopathogenesis of chronic superficial and atrophic gastritis, since it was frequently observed in patients with the gastrointestinal manifestations of Chagas disease. $^{34,77}$

\section{The interstitial cells of Cajal and Chagas disease}

Injury to the interstitial cells of Cajal as well as the enteric nervous system have been considered important in gastrointestinal motility control. ${ }^{78,79}$

Despite the controversy regarding the pathogenic role of defects in the interstitial cells of Cajal in idiopathic constipation and other gastrointestinal motor disorders, changes in the distribution of the interstitial cells of Cajal have been reported in various conditions, such as achalasia, chronic intestinal pseudo-obstruction, infantile hypertrophic pyloric stenosis, Hirschsprung's disease, inflammatory bowel disease and slow transit constipation. ${ }^{77-87}$ In addition, altered distribution of the interstitial cells of Cajal has been demonstrated in chagasic megaesophagus and in chagasic megacolon..$^{27,28,30}$

\section{The incidence of gastrointestinal cancer and Chagas disease}

The association of cancer of the esophagus and megaesophagus has been demonstrated to be both higher and lower in chagasic patients than in normal subjects. ${ }^{33,88}$ Since a higher prevalence of gastric lesions and infection by H. pylori has been demonstrated, an increased incidence of cancer in the chagasic megaesophagus can be expected. ${ }^{34,89-91}$

A review of 4,690 necropsies and 24,209 surgical specimens showed that the prevalence of malignant tumors 
of the large bowel was not higher in chagasic megacolon. ${ }^{32}$ Other authors also showed no association between chagasic megacolon and an increased incidence of cancer. ${ }^{33}$ Thus, Chagas disease affects several gastrointestinal regions, but there is no apparent relationship with the increased incidence of cancer and chagasic megacolon, and the main causes of death in elderly chagasic patients are commonly related instead to heart disease. ${ }^{32,33,92}$

\section{SUMMARY}

Chagas disease is an infectious disease that is described to mainly affect the central nervous system, heart and gastrointestinal tract. The objective of this review is to revise and summarize the main chronic gastrointestinal manifestations described in association with Chagas disease.

Chagas disease is related to several chronic gastro- intestinal disorders resulting from damage to both excitatory and inhibitory enteric motor innervations, leading to megaesophagus, megacolon, megasmall intestine, megagallbladder, megacholedochus, achalasia of the cardia, changes in gastric receptive relaxation, fast gastric emptying of liquid meals, delayed gastric emptying of solid meals, altered small intestine transit and impairment of colon and gallbladder motility.

Chagas disease is also related to hypertrophy of the salivary glands, increased saliva production, decreased acid gastric production and altered small intestinal absorption. In addition, more peptic gastric lesions, a higher incidence of $H$. pylori infection, a similar incidence of cancer in the colon, a higher incidence of cancer in esophagus and altered distribution of the interstitial cells of Cajal in the megaesophagus and megacolon have also been demonstrated in association with Chagas disease.

\section{REFERENCES}

1. Chagas CRJ. Nova tripanosomiaze humana. Memb Inst Oswaldo Cuz. 1909;1:159-218.

2. Campos JV, Tafuri WL. Chagas enteropathy. Gut. 1973;14:910-9.

3. Koberle F. Chagas' disease and Chagas' syndromes: The pathology of American trypanosomiasis. Adv Parasitol. 1968;6:63-116.

4. Bern C, Montgomery SP, Herwaldt BL, Rassi A, Jr., Marin-Neto JA, Dantas RO, et al. Evaluation and treatment of Chagas disease in the United States: A systematic review. JAMA. 2007;298:2171-81.

5. Benchimol Barbosa PR. The oral transmission of Chagas disease: An acute form of infection responsible for regional outbreaks. Int J Cardiol. 2006;112:132-3.

6. Meneghelli UG. Chagas disease: A model of denervation in the study of digestive tract motility. Braz J Med Biol Res. 1985;18:255-64.

7. Dantas RO, Godoy RA. The lower esophageal sphincter in patients with Chagas disease with peristalsis and aperistalsis. Arq Gastroenterol. $1983 ; 20: 13-6$

8. Oliveira RB, Troncon LE, Dantas RO, Menghelli UG. Gastrointestinal manifestations of Chagas disease. Am J Gastroenterol. 1998;93:884-9.

9. Oliveira RB, Rezende Filho J, Dantas RO, Iazigi N. The spectrum of esophageal motor disorders in Chagas disease. Am J Gastroenterol. 1995;90:1119-24

10. Meneghelli UG. Chagasic enteropathy. Rev Soc Bras Med Trop. 2004;37:252-60.

11. Meneghelli UG, Godoy RA, Macedo JF, Oliveira RB, Troncon LE, Dantas RO. Basal motility of dilated and non-dilated sigmoid colon and rectum in Chagas disease. Arq Gastroenterol. 1982;19:127-32.

12. Oliveira RB, Troncon LE, Meneghelli UG, Padovan W, Dantas RO, Godoy RA. Impaired gastric accommodation to distension and rapid gastric emptying in patients with Chagas disease. Dig Dis Sci. $1980 ; 25: 790-4$
13. Lopasso FP, Pinto PE Jr, Gama-Rodrigues JJ. Estudo do esvaziamento gástrico de partículas sólidas digeríveis na gastropatia chagásica crônica. GED. 1985;4:72-8.

14. Troncon LE, Aprile LR, Oliveira RB, Iazigi N. Abnormally rapid gastric emptying of an isosmotic liquid meal in patients with megaduodenum. Dig Dis Sci. 2000;45:2145-50.

15. Troncon LE, Oliveira RB, Romanello LM, Rosa-e-Silva L, Pinto MC, Iazigi N. Abnormal progression of a liquid meal through the stomach and small intestine in patients with Chagas disease. Dig Dis Sci. 1993;38:1511-7.

16. Troncon LE, Rezende Filho J, Iazigi N. Scintigraphic study of gallbladder emptying in chronic Chagas disease. Arq Gastroenterol. $1987 ; 24: 157-63$

17. Villanova MG, Meneghelli UG, Dantas RO. Gallbladder motor function in chagasic patients with megacolon and/or megaesophagus. Digestion. 1987:36:189-94

18. Aprile LR, Troncon LE, Meneghelli UG, Oliveira RB. Small bowel bacterial overgrowth syndrome in chagasic megajejunum: Report of 2 cases. Arq Gastroenterol. 1995;32:71-8.

19. Adad SJ, Cancado CG, Etchebehere RM, Teixeira VP, Gomes UA, Chapadeiro E, et al. Neuron count reevaluation in the myenteric plexus of chagasic megacolon after morphometric neuron analysis. Virchows Arch. 2001;438:254-8.

20. Iantorno G, Bassotti G, Kogan Z, Lumi CM, Cabanne AM, Fisogni S, et al. The enteric nervous system in chagasic and idiopathic megacolon. Am J Surg Pathol. 2007;31:460-8.

21. Crema E, Ribeiro LB, Adad SJ, Ectchebehere RM, Martins Junior A, Silva AA. Gallbladder neuron count in cholelithiasis patients with and without Chagas disease. Rev Soc Bras Med Trop. 2007;40:15-7.

22. Silveira AB, Lemos EM, Adad SJ, Correa-Oliveira R, Furness JB, et al. Megacolon in Chagas disease: A study of inflammatory cells, enteric nerves, and glial cells. Hum Pathol. 2007;38:1256-64. 
23. Takahashi T. Pathophysiological significance of neuronal nitric oxide synthase in the gastrointestinal tract. J Gastroenterol. 2003;38:421-30.

24. Ribeiro Jr. U, Safatle-Ribeiro AV, Habr-Gama A, Gama-Rodrigues JJ, Sohn J, Reynolds JC. Effect of Chagas disease on nitric oxide-containing neurons in severely affected and unaffected intestine. Dis Colon Rectum. 1998;41:1411-7.

25. Silveira AB, D'Avila Reis D, Oliveira EC, Neto SG, Luquetti AO, Poole $D$ et al. Neurochemical coding of the enteric nervous system in chagasic patients with megacolon. Dig Dis Sci. 2007;52:2877-83.

26. Rezende Filho J, Rezende JM, Melo JR. Electrogastrography in patients with Chagas disease. Dig Dis Sci. 2005;50:1882-8.

27. Hagger R, Finlayson C, Kahn F, Oliveira R, Chimelli L, Kumar D. A deficiency of interstitial cells of Cajal in chagasic megacolon. J Auton Nerv Syst. 2000;80:108-11.

28. Geraldino RS, Ferreira AJ, Lima MA, Cabrine-Santos M, Lages-Silva E, Ramirez LE. Interstitial cells of Cajal in patients with chagasic megacolon originating from a region of old endemicity. Pathophysiology. 2006;13:71-4.

29. Oliveira LC, Buso AG, Siqueira Filho L, Moraes F, Oliveira HA, Oliveira RM, et al. Peptic disease and helicobacter pylori are highly prevalent in patients with the indeterminate form of Chagas disease: Report of 21 cases. Rev Inst Med Trop São Paulo. 1997;39:209-12.

30. Lima MA, Cabrine-Santos M, Tavares MG, Gerolin GP, Lages-Silva E, Ramirez LE. Interstitial cells of Cajal in chagasic megaesophagus. Ann Diagn Pathol. 2008;12:271-4.

31. Nascimento RS, Valente SR, Oliveira LC. Seroprevalence of Helicobacter pylori infection in chronic chagasic patients, and in the rural and urban population from Uberlândia, Minas Gerais, Brazil. Rev Inst Med Trop Sao Paulo. 2002;44:251-4.

32. Meneses AC, Lopes MA, Rocha A, Fatureto MC, Lopes GP, Lopes ER, et al. Megas and cancer. Cancer of the large intestine in chagasic patients with megacolon. Arq Gastroenterol. 1989;26:13-6.

33. Garcia SB, Aranha AL, Garcia FR, Basile FV, Pinto AP, de Oliveira EC, et al. A retrospective study of histopathological findings in 894 cases of megacolon: What is the relationship between megacolon and colonic cancer? Rev Inst Med Trop São Paulo. 2003;45:91-3.

34. Barbosa AJ, Queiroz DM, Nogueira AM, Roquette Reis MJ, Mendes EN, Rocha GA, et al. Chronic gastritis and helicobacter pylori in digestive form of Chagas disease. Rev Inst Med Trop Sao Paulo. 1993;35:117-21.

35. Lopes ER, Rocha A, Meneses AC, Lopes MA, Fatureto MC, Lopes GP, et al. Prevalence of visceromegalies in necropsies carried out in Triângulo Mineiro from 1954 to 1988. Rev Soc Bras Med Trop. 1989;22:211-5.

36. Boyce HW, Bakheet MR: Sialorrhea. A review of a vexing, often unrecognized sign of oropharyngeal and esophageal disease. J Clin Gastroenterol. 2005;39:89-97.

37. Tyler I, Birmingham CL. The interrater reliability of physical signs in patients with eating disorders. Int J Eat Disord. 2001;30:343-5.

38. Price C, Schmidt MA, Adam EJ, Lacey H. Parotid gland enlargement in eating disorders: An insensitive sign? Eat Weight Disord. 2008;13:79-83.

39. Dantas RO, Godoy RA, Oliveira RB, Meneghelli UG, Troncon LE. Lower esophageal sphincter pressure in Chagas disease. Dig Dis Sci. 1990;35:508-12.
40. Padovan W, Godoy RA, Dantas RO, Meneghelli UG, Oliveira RB, Troncon LE. Lower oesophageal sphincter response to pentagastrin in chagasic patients with megaoesophagus and megacolon. Gut. 1980;21:85-90

41. Holmes GW, Dresser R. The use of amyl nitrite as an antispasmodic in the roentgen examination of the gastrointestinal tract. Am J Roentgenol Radium Ther. 1928;19:44-47.

42. Ritvo M, McDonald EJ. The value of nitrites in cardiospasm (achalasia of the esophagus). Am J Roentgenol Radium Ther. 1940;43:500-8.

43. Douthwaite AH. Achalasia of the cardia. Lancet. 1943;2:353-4.

44. Field CE. Octil nitrite in achalasia of the cardia. Lancet. 1944;2:848-51.

45. Gelfond M, Rozen P, Keren S, Gilat T. Effect of nitrates on los pressure in achalasia: A potential therapeutic aid. Gut. 1981;22:312-8.

46. Gelfond M, Rozen P, Gilat T. Isosorbide dinitrate and nifedipine treatment of achalasia: A clinical, manometric and radionuclide evaluation. Gastroenterology. 1982;83:963-9.

47. Rozen P, Gelfond M, Salzman S, Baron J, Gilat T. Radionuclide confirmation of the therapeutic value of isosorbide dinitrate in relieving the dysphagia in achalasia. J Clin Gastroenterol. 1982;4:17-22.

48. Dantas RO, Godoy RA, Oliveira RB, Meneghelli UG, Troncon LE. Effect of isosorbide dinitrate and atropine on the lower esophageal sphincter pressure in chagasic patients. Acta Physiol Pharmacol Latinoam. 1988;38:151-8.

49. Dantas RO, Godoy RA, Oliveira RB, Villanova MG, Meneghelli UG, Troncon LE. Effect of nifedipine on the lower esophageal sphincter pressure in chagasic patients. Braz J Med Biol Res. 1986;19:205-9.

50. Oliveira RB, Matsuda NM, Figueiredo MC, Okano N, Vargas EC Comparison of the effects of sublingual isosorbide dinitrate and cardiomyotomy on esophageal emptying in patients with chagasic megaesophagus. Arq Gastroenterol. 1994;31:47-51.

51. Ferreira-Filho LP, Patto RJ, Troncon LE, Oliveira RB. Use of isosorbide dinitrate for the symptomatic treatment of patients with Chagas disease achalasia. A double-blind, crossover trial. Braz J Med Biol Res. 1991;24:1093-8.

52. Figueiredo MC, Oliveira RB, Iazigi N, Matsuda NM. Short report: Comparison of the effects of sublingual nifedipine and isosorbide dinitrate on oesophageal emptying in patients with chagasic achalasia. Aliment Pharmacol Ther. 1992;6:507-12.

53. Matsuda NM, Oliveira RB, Dantas RO, Iazigi N: Effect of isosorbide dinitrate on gastroesophageal reflux in healthy volunteers and patients with Chagas disease. Dig Dis Sci. 1995;40:177-82

54. Bult H, Boeckxstaens GE, Pelckmans PA, Jordaens FH, Van Maercke YM, Herman AG. Nitric oxide as an inhibitory non-adrenergic noncholinergic neurotransmitter. Nature. 1990;345:346-47.

55. Rand MJ. Nitrergic transmission: Nitric oxide as a mediator of nonadrenergic, non-cholinergic neuro-effector transmission. Clin Exp Pharmacol Physiol. 1992;19:147-69.

56. Dantas RO. Idiopathic achalasia and chagasic megaesophagus. J Clin Gastroenterol. 1988;10:13-5.

57. Dantas RO. Comparison between idiopathic achalasia and achalasia caused by Chagas disease: A review on the publications about the subject. Arq Gastroenterol. 2003;40:126-30. 
58. Herbella FA, Oliveira DR, Del Grande JC. Are idiopathic and chagasic achalasia two different diseases? Dig Dis Sci. 2004;49:353-60.

59. Agrawal A, Hila A, Tutuian R, Castell DO. Manometry and impedance characteristics of achalasia. Facts and myths. J Clin Gastroenterol. $2008 ; 42 ; 266-70$.

60. Kraichely RE, Farrugia G. Achalasia: Physiology and etiopathogenesis. Dis Esophagus. 2006;19:213-23.

61. Mearin F, Mourelle M, Guarner F, Salas A, Riveros-Moreno V, Moncada $\mathrm{S}$, et al. Patients with achalasia lack nitric oxide synthase in the gastrooesophageal junction. Eur J Clin Invest. 1993;23:724-8.

62. Ahmed A. Achalasia: What is the best treatment? Ann Afr Med. 2008;7:141-8

63. Campos GM, Vittinghoff E, Rabl C, Takata M, Gadenstatter M, Lin F, et al. Endoscopic and surgical treatments for achalasia: A systematic review and meta-analysis. Ann Surg. 2009;249:45-57.

64. Pinotti HW, Felix VN, Zilberstein B, Cecconello I. Surgical complications of Chagas' disease: Megaesophagus, achalasia of the pylorus, and cholelithiasis. World J Surg. 1991;15:198-204.

65. Troncon LE, Oliveira RB, Meneghelli UG, Dantas RO, Godoy RA. Fasting and food-stimulated plasma gastrin levels in chronic Chagas disease. Digestion. 1984;29:171-6.

66. Troncon LE, Oliveira RB, Meneghelli UG, Dantas RO, Godoy RA. Plasma gastrin and gastric acid responses to insulin hypoglycemia in Chagas disease. Braz J Med Biol Res. 1985;18:273-8.

67. Oliveira RB, Meneghelli UG, Godoy RA, Dantas RO, Padovan W. Abnormalities of interdigestive motility of the small intestine in patients with Chagas disease. Dig Dis Sci. 1983;28:294-9.

68. Cavenaghi S, Felicio OC, Ronchi LS, Cunrath GS, Melo MM, Netinho JG. Prevalence of rectoanal inhibitory reflex in chagasic megacolon. Arq Gastroenterol. 2008;45:128-31.

69. Morais MB, Sdepanian VL, Tahan S, Goshima S, Soares AC, Motta ME, et al. Effectiveness of anorectal manometry using the balloon method to identify the inhibitory recto-anal reflex for diagnosis of Hirschsprung's disease. Rev Assoc Med Bras. 2005;51:313-7.

70. Gladman MA, Knowles CH. Novel concepts in the diagnosis, pathophysiology and management of idiopathic megabowel. Colorectal Dis. 2008;10:531-8.

71. Garcia RL, Matos BM, Feres O, Rocha JJ. Surgical treatment of Chagas megacolon. Critical analysis of outcome in operative methods. Acta Cir Bras. 2008;23:83-92.

72. Cutait DE, Cutait R. Surgery of chagasic megacolon: World J Surg. 1991;15:188-97.

73. Meneghelli UG, Martinelli AL, Martucci NC, Romanello LM, Dantas RO. Incidence of diverticular disease of the large bowel in nonchagasic and chagasic individuals with and without megacolon. Arq Gastroenterol. 1986;23:3-8.

74. Oliveira LC, Nascimento RS, Rocha A, Goncalves EG, Silva JM, Oliveira VA, et al. Cholelithiasis in chronic Chagas disease patients. Arq Gastroenterol. 1997;34:222-6.

75. Rocha A, Almeida HO, Teixeira VP, Silva AM. Prevalence of cholelithiasis in necropsies of patients with chronic Chagas' disease in the mining triangle--correlation with megaesophagus, megacolon and cardiac insufficiency. Arq Gastroenterol. 1085;22:3-6.
76. Mazzoleni LE, Sander GB, Ott EA, Barros SG, Francesconi CF, Polanczyk CA, et al. Clinical outcomes of eradication of helicobacter pylori in nonulcer dyspepsia in a population with a high prevalence of infection: Results of a 12-month randomized, double blind, placebocontrolled study. Dig Dis Sci, 2006;51:89-98.

77. Smith DS, Williams CS, Ferris CD. Diagnosis and treatment of chronic gastroparesis and chronic intestinal pseudo-obstruction. Gastroenterol Clin North Am. 2003;32:619-58.

78. Negreanu LM, Assor P, Mateescu B, Cirstoiu C. Interstitial cells of Cajal in the gut--a gastroenterologist's point of view. World J Gastroenterol. $2008 ; 14: 6285-8$

79. Hasler WL. Is constipation caused by a loss of colonic interstitial cells of Cajal? Gastroenterology. 2003;125:264-5.

80. Farrugia G. Interstitial cells of Cajal in health and disease. Neurogastroenterol Motil. 2008;20:54-63.

81. Tong WD, Liu BH, Zhang LY, Zhang SB, Lei Y. Decreased interstitial cells of Cajal in the sigmoid colon of patients with slow transit constipation. Int J Colorectal Dis. 2004;19:467-73.

82. Lyford GL, He CL, Soffer E, Hull TL, Strong SA, Senagore AJ, et al. Pan-colonic decrease in interstitial cells of Cajal in patients with slow transit constipation. Gut. 2002;51:496-501.

83. Kilic A, Luketich JD, Landreneau RJ, Owens SR, Krasinskas AM, Schuchert MJ. Alterations in the density of interstitial cells of Cajal in achalasia. Dig Dis Sci. 2008;53:1488-92.

84. Gockel I, Bohl JR, Eckardt VF, Junginger T. Reduction of interstitial cells of Cajal (ICC) associated with neuronal nitric oxide synthase (n-NOS) in patients with achalasia. Am J Gastroenterol. 2008;103:856-64.

85. Wang $\mathrm{H}$, Zhang $\mathrm{Y}$, Liu W, Wu R, Chen $\mathrm{X}, \mathrm{Gu} \mathrm{L}$ et al. Interstitial cells of Cajal reduce in number in recto-sigmoid Hirschsprung's disease and total colonic aganglionosis. Neurosci Lett. 2009;451:208-11.

86. Miller SM, Narasimhan RA, Schmalz PF, Soffer EE, Walsh RM, Krishnamurthi V et al. Distribution of interstitial cells of Cajal and nitrergic neurons in normal and diabetic human appendix. Neurogastroenterol Motil. 2008;20:349-57.

87. Feldstein AE, Miller SM, El-Youssef M, Rodeberg D, Lindor NM, Burgart LJ et al. Chronic intestinal pseudoobstruction associated with altered interstitial cells of Cajal networks. J Pediatr Gastroenterol Nutr. 2003;36:492-7.

88. Rezende JM, Rosa H, Vaz MG, Andrade-Sa N, Porto JD, Neves Neto $\mathrm{J}$ et al. Endoscopy in megaesophagus. Prospective study of 600 cases. Arq Gastroenterol. 1985;22:53-62.

89. Eslick GD, Lim LL, Byles JE, Xia HH, Talley NJ. Association of Helicobacter pylori infection with gastric carcinoma: A meta-analysis. Am J Gastroenterol. 1999;94:2373-9.

90. El-Omar EM, Oien K, Murray LS, El-Nujumi A, Wirz A, Gillen D et al. Increased prevalence of precancerous changes in relatives of gastric cancer patients: Critical role of H. pylori. Gastroenterology. 2000;118:22-30

91. Cheung TK, Wong BC. Treatment of Helicobacter pylori and prevention of gastric cancer. J Dig Dis. 2008;9:8-13.

92. Menezes M, Rocha A, Silva AC, Silva AM. Basic causes of death in elderly patients with Chagas disease. Arq Bras Cardiol. 1989;52:75-8. 